\title{
O USO DE DISPOSITIVOS MIIIÁTICOS DIGITAIS NA COMUNICACCÃO E ELABORAÇÃO DE ESTRATÉGIAS CONTRA- HEGEMÔNICAS PELO MOVIMENTO DO AUDIOVISUAL PARAIBANO
}

\section{THE USE OF DIGITAL MEDIA DEVICES IN THE COMMUNICATION AND THE ELABORATION OF COUNTER-HEGEMONIC STRATEGIES FOR THE AUDIOVISUAL MOVEMENT IN PARAÍBA}

\author{
Kleyton Jorge CANUTO ${ }^{2}$ \\ Juciano de Sousa LACERDA ${ }^{3}$
}

Resumo: Este artigo tem como tema o Movimento do Audiovisual Paraibano e sua apropriação dos dispositivos midiáticos digitais para otimizar suas estratégias de reivindicação de demandas para o setor e de que maneira esse movimento contribui para a mídia independente paraibana. Nossa proposta é apresentar uma reflexão teórica sobre as potencialidades de uso de dispositivos midiáticos digitais pelos movimentos sociais no contexto da contra-hegemonia, além de fazer um preâmbulo descritivo sobre o Movimento do Audiovisual da Paraíba e seu contexto na mídia independente.

\footnotetext{
${ }^{1}$ A primeira versão deste artigo foi apresentada no GP Comunicação para Cidadania do XII Encontro dos Grupos de Pesquisa em Comunicação, evento componente do XXXV Congresso Brasileiro de Ciências da Comunicação, na Unifor, em Fortaleza-CE.

${ }^{2}$ Mestrando em Estudos da Mídia pela Universidade Federal do Rio Grande do Norte (UFRN), bolsista Capes DS, possui graduação em comunicação social pela Universidade Estadual da Paraíba (UEPB). É conselheiro municipal de cultura da cidade de Campina Grande (PB) representando o audiovisual. Integra o coletivo Moinho de cinema da Paraíba desempenhando as funções de diretor, ator e produtor. É integrante do LAPECCOS no Grupo de Pesquisa PRAGMA/UFRN/CNPq. Email: kleytonknuto@gmail.com

${ }^{3}$ Docente do PPG em Estudos da Mídia da UFRN. Doutor em Ciências da Comunicação (Unisinos, 2008), com Estágio Doutoral na UAB-Espanha (2005-06, Capes/MECD). Coordena o GP Comunicação para a Cidadania da INTERCOM (2013-14). Coordena o LAPECCOS - Laboratório de Pesquisa e Estudos em Comunicação Comunitária e Saúde Coletiva (filiado ao GP PRAGMA/CNPq e NESC/UFRN). Integra o Instituto Nacional de Pesquisa em Comunicação Comunitária (LECC-UFRJ/LAPECCOS-UFRN/LACOPsUFF). E-mail: juciano.lacerda @ gmail.com
} 


\section{míDiA \\ ecc DiAno}

Palavras-Chave: Audiovisual; movimentos sociais; dispositivos midiáticos; Internet; contra-hegemonia.

Abstract: This article focuses on the Audiovisual Movement in Paraiba and its appropriation of digital media devices in order to optimize demand strategies regarding the audiovisual sector and how this movement contributes to the independent media of the state. Our purpose is not only to present a theoretical reflection on the potentialities of the use of digital media devices by social movements in the counter-hegemonic scenery, but also to compose a descriptive preamble about the Audiovisual Movement in Paraíba and its context in the local independent media.

Keywords: Audiovisual; social movements; media devices; Internet; counter-hegemony

\section{Introdução}

Com a disseminação da Internet a partir dos anos 1990, muito se falou sobre a quebra dos padrões tradicionais de comunicação e sobre uma pretensa revolução no campo da informação. Neste contexto, a Internet desempenha, em tese, o papel de anular a tradicional dicotomia emissor/receptor e possibilitar canais informação e comunicação dialógicos, horizontais e eminentemente democráticos.

Sabe-se que a Internet permitiu novas fronteiras de atuação dos movimentos sociais, fazendo com que as antes 'vozes roucas' abafadas pelas grandes mídias ganhassem novos espaços. A utilização de mídias digitais por esses movimentos sociais possibilitou diferentes formas de transmitir informações e ofereceu canais de participação mais identificados com o espaço público.

O movimento do audiovisual paraibano, vanguardista por sua história, a partir dos anos 2000, começa a utilizar dispositivos midiáticos digitais para a melhoria da articulação e comunicação de seus membros, aproximando entidades, efetivando uma participação pluralista na elaboração de táticas e estratégias de atuação de postura contra-hegemônica em favor da democratização do acesso ao audiovisual local. Isso irá desencadear em ações práticas sociais como festivais, fóruns, mobilizações, criação de novos espaços para exibição, qualificação técnica, crescimento na produção de curtas metragens.

No entanto, deve-se escapar da armadilha que consiste em exaltar as qualidades de um meio que aparentemente possibilita a democratização plena da informação e alça o 


\section{míDiA \\ D \\ DiAno}

ativismo social para níveis antes inimagináveis. Por outro lado, é igualmente ingênuo demonizar internet como um meio que distancia fisicamente as pessoas, aliena os usuários e permite todo tipo de "falsificação" das notícias. O fato é que este é um campo de estudos muito recente, e a Internet, como toda tecnologia, depende da significação que lhe é socialmente atribuída.

Nesse sentido, contextualizando o objeto em estudo, algumas questões emergem. Como as entidades que fazem parte do Movimento do Audiovisual Paraibano se apropriam das Tecnologias de Informação e Comunicação (TIC's) em suas ações afirmativas, contribuindo para a configuração de uma Mídia Independente paraibana? Para obter uma resposta minimante coerente para que possibilite um prosseguimento em nossa pesquisa é necessário elucidar outras prerrogativas norteadoras a fim aperfeiçoar a composição de nosso pensamento. Sendo assim, emergem outros questionamentos que exigem um aprofundamento no tema. Como o movimento do audiovisual paraibano se apropria das TIC's para reivindicar suas demandas? Quais são as TIC's utilizadas pelo movimento e como se opera a sua dinâmica de debate? De que forma o movimento do audiovisual paraibano colabora com a cidadania cultural? Como as discussões no âmbito virtual podem resultar em ações práticas sociais como os festivais, fóruns políticas públicas voltadas na área? E que nível as ações do movimento do audiovisual paraibano contribui com a chamada democratização da informação?

Este artigo é fruto de uma pesquisa de mestrado em andamento, cujo objetivo é responder aos questionamentos levantados acima, através do estudo das entidades que compõem o movimento de audiovisual paraibano e que se utilizam da internet das seguintes formas: como ferramenta de reivindicação de suas demandas; como articulação de atividades e políticas; como forma de estabelecer um canal direto com seu público alvo; ou, ainda, como maneira de divulgar e publicizar suas ações para o meio cibernético em geral. Antes de adentrar na pesquisa propriamente dita, esboçaremos os principais referenciais teóricos que orientam a análise do nosso objeto de estudo.

\section{Sociedade civil organizada, movimentos sociais e contra-hegemonia}




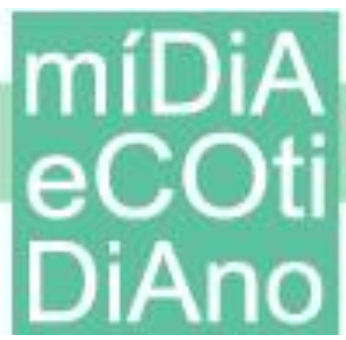

PPGMC

A sociedade civil organizada sempre desempenhou um papel de grande importância no cenário político de uma sociedade. Reivindicando em prol dos setores marginalizados pelas políticas públicas de estado e contrapondo as pressões dos setores privados dominantes, os movimentos sociais de caráter popular integram um dos pilares vitais para manutenção do sistema democrático (DAGNINO apud BURGOS, 2007).

Desde o estabelecimento dos estados democráticos modernos, a sociedade como um todo se via amparada pela a figura do Estado como provedor e gerenciador dos direitos e políticas para toda população; além disso, tinha a arena política partidária, com seus órgãos competentes, como principal campo de formulação e deliberação de políticas para a sociedade.

Contudo, com o desnivelamento das demandas em relação a certos grupos ou a não satisfação com tais políticas, ora favorecendo a centralidade do Estado ora favorecendo o controle de uma elite privada, emergiram contradições sociais que motivaram a parte excluída a se organizar através de ações coletivas em prol de suas reivindicações, criando um novo ator político: os movimentos sociais (FESTA, 1986, p. 11).

Segundo Regina Festa:

Os movimentos sociais não ocorrem por acaso. Eles têm origem nas contradições sociais que levam parcelas ou toda população a buscar formas de conquistar ou reconquistar espaços democráticos negados pela classe de poder, e postulam novos espaços sociais, ora através de confrontação ora por participação (idem, 1986, p. 11-13).

Considerando isto, é válido ressaltar que os movimentos sociais nascem nas tensões entre classes sociais mediante a uma conjuntura de desequilíbrio de forças diante da hegemonia do Estado. O Conceito de hegemonia, trabalhado por Gramsci, remete o que está organicamente ligado ao Estado, perfaz pela relação também orgânica entre sociedade política e sociedade civil, o que elevado ao longo do tempo a ser chamada de 'espaço público não estatal' (BURGOS, 2007, p. 128 -130) e dotada de caráter político legítimo, como pode afirmar a cientista política Evelina Dagnino:

A ação política não se limita a sociedade política, como a teoria da sociedade civil sustenta, mas é parte lógica da sociedade civil, cujos autores, ao defender projetos na esfera pública e desenvolver a ação coletiva, estão fazendo política, disputando espaços de poder e orientando a política pública. Gramsci [...] mostra que a sociedade civil é terreno do poder e, portanto, campo da ação política (DAGNINO apud BURGOS, 2007). 
Em oposição à ideia de hegemonia, se atribui o conceito de contra-hegemonia, em que essa oposição se manifesta no sentido restritivamente antagônico e não de substituição ao hegemônico, numa ideia de distanciamento ideológico pautado em ideais que geram uma constante ação e reflexão contundente ao status quo vigorado (PAIVA, 2008). Dagnino ainda ressalta que há uma heterogeneidade de atores civis, e que no seu cerne, inclusive possam existir projetos nem tão civis muito menos democratizantes, configurando uma arena plural de lutas e conflitos (idem, 2007).

Esta definição aproxima-se muito da ideia de sociedade civil de Dênis de Moraes. O autor associa esse posicionamento - também sob influência gramsciana - ressaltando que nessa arena, atuam aparelhos autônomos do Estado que buscam estabelecer consenso seja para manutenção ou reversão dos padrões dominantes. E compreende que a hegemonia não se reduz à força e correção, mas é resultado tanto de embates entre visões de mundo e valores no interior de uma sociedade, quanto das mediações de forças entre blocos sociais em determinado contexto histórico (MORAES, 2008).

Os movimentos sociais se diferenciam da sociedade civil organizada, tanto pela não subordinação de uma pela outra, como também pelo fato dos movimentos sociais populares operarem na lógica da oposição e da contra-hegemonia, sendo uma das expressões mais dinâmicas de resistência (DOWNING, 2002). Enquanto isso, a sociedade civil organizada é composta, também, por entidades pró-hegemônica, conservadoras e diretamente ligada às instituições de poder vigente, criando um jogo de disputa interna em que Scott irá chamar de infrapolítica (SCOTT in DOWNING, 2002).

Nesse contexto, os movimentos sociais utilizam as mais variadas estratégias para alcançar suas demandas e publicizar suas reivindicações ao conhecimento da população, bem como manter sua articulação interna (FESTA, 1986). Os veículos de comunicação alternativos se configuram entre as principais ferramentas de manifestação das demandas dos movimentos sociais populares, de esquerda e de cultura de oposição e fizeram com que ao longo da história estes movimentos se adaptaram as transformações midiáticas, estabelecendo o campo ao qual se denominou mídia independente e/ou alternativa (DOWNING, 2010). 


\section{míDiA \\ eCOt \\ DiAno}

\section{Movimentos sociais e mídia independente e suas relações com internet}

Entre os instrumentos de atuação dos movimentos sociais ao longo dos tempos, os meios de comunicação são agentes propagadores e informativos do discurso destes, o que se configuram como mídia independente ou alternativa, bem como dentre as demandas dos movimentos estão questões relativas à própria comunicação (FESTA, 1986; RAMOS, 2005).

O que podemos definir como mídia independente ou mídia alternativa? Se empregarmos o conceito de Herman e Chomsky, mídia independente se caracteriza como "mídia informativa não corporativa, não estatal e não religiosa (DOWNING, 2010, p. 52)", embora não se excluam outros propósitos senão o informativo. Neste sentido, o conceito guarda semelhanças com a discussão sobre comunicação popular, comunitária e alternativa desenvolvida por Peruzzo (2010). A autora atribui a este tipo de comunicação um caráter civil popular, não governamental e não empresarial, e vem a elencar como suas principais características a ausência de fins lucrativos, a participação ativa e aberta e o tratamento de conteúdos que estão "em sintonia com a realidade local, ou com a comunidade de interesse a que se vincula" (PERUZZO, 2010, p. 4).

Em uma posição mais crítica, John Downing questiona a assertiva 'alternativa' seguindo a lógica uma coisa sempre é alternativa a algo (DOWNING, 2012. p. 52). O autor inglês prefere se referir a todo esse espectro, acrescentando outras definições de mídia contra-hegemônicas - a exemplo de mídia comunitária, mídia tática, mídia participativa, etc. - ao que ele denomina de 'Mídia dos Movimentos Sociais', usando uma perspectiva plural, desprezando formatos, gêneros, alcances e finalidades e um único ponto de confluência é o pouco ou não financiamento - em relação à mídia hegemônica - na sua elaboração e disseminação.

Mesmo assim, nos inclinamos ao conceito de mídia independente de Herman e Chomsky, mas englobando também aspectos da comunicação comunitária e alternativa proposta por Peruzzo, a exemplo da presença de processos não hierarquizados e compartilhados de produção e difusão de mensagens e da propriedade coletiva. Tal escolha parte pela premissa de delimitação direcionada ao objeto, o que nos auxiliará na filtragem 


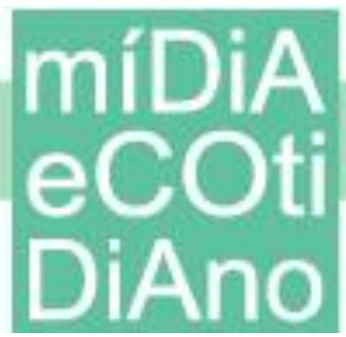

de componentes a serem estudados com tal definição. No entanto, consideramos o questionamento de John Downing, de maneira que o termo 'alternativo' venha a ser automaticamente relacionado ao termo 'independente'.

Por fim, se faz pertinente uma breve discussão sobre o papel da mídia independente, a atuação na internet e o reflexo nos movimentos sociais. As mídias independentes, para Festa se desenvolvem na mesma capacidade de articulação dos movimentos sociais, decorrentes do "processo político social e que, enquanto instrumentos, são capazes por si mesmos de alterar de forma substantiva a realidade social (FESTA, 1986, p.30)”.

Contextualizando com a Internet, Manuel Castells adenda o pensamento de Festa, afirmando que:

\begin{abstract}
Os movimentos sociais do século XXI, ações coletivas deliberadas que visam à transformação de valores e instituições da sociedade, manifestam-se na e pela Internet [...] Ela se ajusta as características básicas do tipo de movimento social que está surgindo na Era da Informação. E como encontraram nela seu meio apropriado de organização, esse movimentos abriram e desenvolveram novas avenidas de troca social, que, por sua vez, aumentaram o papel da Internet como sua mídia privilegiada (CASTELLS, 2003, p.114-115).
\end{abstract}

Esse potencial da Internet como ferramenta de operação e debate, troca informativa e aproximação de identidades é elucidado por Moraes, em que "redes distinguem-se como sistemas organizacionais com estruturas flexíveis e colaborativas baseadas em afinidades, objetivos e temáticas comuns entre os integrantes, a partir da regra ou modalidade de convívio compartilhado" (MORAES, 2008, p. 43).

$\mathrm{Na}$ medida em que grupos se organizam através da Internet, passam a recorrer à utilização das interfaces propostas pelo sistema. Porém, muitas das ferramentas midiáticas possuem uma finalidade original (programada) distinta dos propósitos de uso dos grupos e coletivos. Muitas vezes, o uso pelos grupos pode ser entendido como uma ação instrumentalizada, por um ajuste dos interesses próprios à lógica do sistema midiático, àquilo que é da "ordem de uso". Segundo Lacerda e Maziviero:

Assim, há uma trama, ligação, pacto, tensões e disputas entre aquilo que é da ordem de uso - o que é proposto, embutido, pré-determinado, codificado e estabelecido como finalidade dos produtos midiáticos, textos, mensagens[...] e tecnologias da informação e comunicação - e o que é da (des)ordem da apropriação - formas de uso marginal, margens de manobra, astúcias, bricolagens, maneiras de empregar, formas desviantes, palimpestos, etc (LACERDA \& MAZIVIERO, 2011, p. 7). 


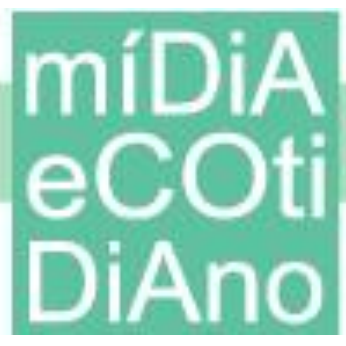

Ao relacionarmos estas definições ao panorama do audiovisual paraibano enquanto organização social que se articula por via das mídias digitais - entre elas redes sociais que possuem um intuito lúdico (a exemplo do Facebook) - deduzimos que venha a existir uma apropriação de tais ferramentas para o uso de debates, fóruns, articulações e conversas informais que gerem estratégias e táticas em prol do movimento.

Por fim, não podemos descartar que o mesmo ambiente está sujeito a tensões e conflitos inerentes ao seu caráter plural e colaborativo, visto que mesmo nos microcosmos dos coletivos é notável também uma disputa hegemônica, onde pressupomos que o caráter e bem comum do movimento venha se prevalecer. Por esse motivo, acreditamos que a internet seja um campo frutífero e bem relacionado com as linhas de atuação dos movimentos sociais, otimizando suas ações.

\section{Ciberespaço, socialidades e democracia: potencialidades e limites}

Em linhas gerais, o que diferencia a Internet dos demais meios de comunicação, no caráter de fluxo de informação, é que enquanto a comunicação de massa (rádio, televisão, impressos) e a comunicação individual (correios e telefone), operam por um fluxo de informação "um para todos" ou "um - um" - operando assim, por uma lógica de oferta e subsequentemente garantindo o controle da emissão -, a Internet quebra essa ordem. Gera processos que conectam usuários, criando um fluxo bi ou multidirecional de informação, ou seja, um modelo "todos - todos" (preferivelmente "muitos - muitos"), direcionado ao acesso, que opera por uma lógica da demanda (WOLTON, 2007). Assim, em teoria, nas interfaces digitais, a participação, a produção e a disseminação de informações tornam-se mais ampliadas e plurais, estabelecendo um sentido prático ao conceito de comunicação.

Como nos lembra Simmel (apud GARCIA, 2007) no entanto, o homem, apesar de possuir hoje a luz elétrica, esquece de que o essencial não é a luz em si, mas aquilo que ela torna mais visível. Neste sentido, é preciso olhar não apenas para como a tecnologia Internet foi criada ou quais seus potenciais embutidos, mas também, e talvez principalmente, para as configurações sociais com as quais ela se relaciona. Talvez por isso 


\section{míDiA \\ ecc DiAno}

Castells (2003, p. 258) enfatiza que a Internet, além de tecnologia, é um meio de interação e organização social sobre o qual se baseia a sociedade em que vivemos, que ele chama de Sociedade em Rede. ${ }^{4}$ Esta perspectiva, da Rede para além de sua característica de ferramenta, abre interessantes debates.

Pierre Lévy (1999, p.63) afirma que o ciberespaço, no qual a Internet se insere, "torna disponível um dispositivo comunicacional original, já que ele permite que as comunidades constituam de forma progressiva e de maneira cooperativa um contexto comum”. Para o autor, evidente entusiasta das NTCs (Novas Tecnologias de Comunicação), a participação democrática e as formas de ação política foram definitivamente impulsionadas e redefinidas pela era digital; estruturas burocráticas e partidárias foram substituídas por organizações abertas, horizontais e dinâmicas, que tendem a ampliar a pressão da sociedade civil sobre as democracias representativas.

Dominique Wolton (2007, p. 96), por seu turno, alerta para a concepção que sustenta os novos serviços de informação, os quais seriam reflexo "menos de um esforço de democratização do que de uma especialização das informações em função dos diferentes meios solváveis". Segundo o autor, ainda que o acesso a meios como a Internet seja livre, o tipo de informação disseminada é especializada em função dos públicos e selecionada a partir do nível econômico e cultural. O risco, neste caso, é de que a posição social determine o nível da demanda por informação, impossibilitando, assim, uma atitude de questionamento e emancipação - o que leva Wolton (idem, p. 97) a afirmar que meios como jornais, rádios e televisão são mais democráticos, pois são “instrumentos de comunicação que atuam no universal e não no particular".

Um ponto de vista diferente sobre a organização comunitária diante das NTCs pode ser encontrado em Maffesoli (1998). Em sua discussão sobre o neotribalismo, o autor, embora não incorra diretamente no debate da Internet, oferece chaves importantes de pesquisa. Para Maffesoli, a teoria social criou o paradigma da racionalidade ascendente nas

\footnotetext{
${ }^{4}$ Que também dá título ao livro de Manuel Castells “A Sociedade em Rede” (Ed. Paz e Terra, 2007).

${ }^{5}$ A título de observação, podemos responder à assertiva de Wolton (2007, p. 102) segundo a qual a Internet não é, essencialmente, uma mídia, mas "um formidável sistema de transmissão e de acesso a um número incalculável de informações", afirmando que ainda que assim seja, isso não impede que a Net esteja permeada por mídias, inclusive mídias independentes. Este debate poderá desenvolver-se em reflexões ulteriores nesta pesquisa sobre o significado da Internet e a recontextualização da democracia perante esse meio.
} 


\section{míDiA \\ 次 \\ DiAno}

sociedades modernas (tema presente, em diferentes formas, em Weber, Durkheim e Marx). Essas análises "insistiram tanto na desumanização, no desencantamento do mundo moderno, na solidão que este engendra, que não conseguem mais ver as redes de solidariedade que nele se constituem" (idem, p. 101). Nas sociedades contemporâneas surge um novo ethos que atende à necessidade de estar-junto, que atende às socialidades: fluidas, eletivas, comunitárias. A Internet parece ser um terreno extremamente fértil para este tipo de experiência, na medida em que propicia, para os instruídos em sua técnica, um mundo onde nunca se está só: a Rede é seara de qualquer tipo de experiência coletiva, desde a organização dos novos movimentos sociais, como o eco ativismo, até manifestações preconceituosas e racistas, tão antigas quanto a própria cultura. $\mathrm{Na}$ perspectiva de Maffesoli, o neotribalismo "recusa reconhecer- se em qualquer projeto político, não se inscreve em nenhuma finalidade e tem como única razão de ser a preocupação com um presente vivido coletivamente" (idem, p. 105). Em oposição ao social, onde o indivíduo desempenha uma função na sociedade, segue uma estratégia, através de um partido, classe ou grupo estável, a socialidade implica na dispersão do projeto político mediante um sujeito-ator, que muda de pretensões e ações a depender do papel que deseja desempenhar no teatro-mundo.

A Internet se apresenta como um território onde ações políticas eficazes e comunidades efêmeras e sentimentais podem coexistir. Há um consenso entre os teóricos do tema, mesmo os mais entusiastas, que a técnica não basta para garantir a democracia da comunicação. A ampliação dos espaços democráticos concorre, entre muitos outros fatores, com a crescente privatização das informações, de modo que as potencialidades do instrumento nesta direção ainda não foram plenamente exploradas.

Atualmente, a internet se caracteriza como uma plataforma para atuação dessas mídias, por seu fácil alcance e possibilidade de uma comunicação de muitos para muitos, configurando a rede como principal instrumento de luta e apelo das demandas dos movimentos sociais. Seu 'ecossistema digital', descentralizado, de utilização simultânea e múltiplos emissores permite uma variedade de usos e experiências de produção e difusão de conteúdos diferenciados e alternativos à mídia pragmática (MORAES, 2008). Esse panorama se estabeleceu em grande parte do planeta, a ponto de entidades como a 


\section{míDiA \\ eCo \\ DiAno}

UNESCO - braço das Nações Unidas responsável pela ciência, educação e cultura - se inclinarem a pesquisar e estudar o mundo virtual e suas potencialidades (PASQUALI, 2005) (RAMOS, 2005), redimensionando as relações sociais e de poder a outro patamar.

Considerando o panorama brasileiro, diversos movimentos utilizam e se apropriam das mídias digitais e da plataforma da web enquanto campo de atuação discursiva e produção de conteúdo - a exemplo do $\mathrm{CMI}^{6}$ (Centro de Mídia Independente) e do portal Intervozes $^{7}$ - bem como ferramenta de organização interna e canal de diálogo com a população. O crescimento do acesso às tecnologias de informação e comunicação (TIC's) ${ }^{8}$ permite uma evidência maior na atuação destes movimentos, assim como uma audiência mais ativa, variada com caráter participativo e colaborativo (DOWNING, 2002) mediante a dinâmica de cada movimento social e suas entidades.

No Estado da Paraíba não é diferente. Sites das mais variadas categorias e finalidades de interesse sociocultural compõem uma frente paralela de informação e comunicação ante as chamadas mídias oficial (Estado) e hegemônica (privado), criando uma mídia independente e alternativa, se apropriando das mídias digitais como ferramentas de articulação, debate e ação tática para galgar novos campos de atuação, propor políticas de interesse coletivo e almejar uma cidadania cultural efetiva.

\section{O Movimento Audiovisual Paraibano e sua articulação com a internet}

Nossa pesquisa prioriza entidades que utilizam dispositivos midiáticos de informação, participação e colaboração inseridas nas características da comunicação alternativa e comunitária, seja devido ao conteúdo das interpretações expostas, que divergem daquelas contidas em sites subordinados a grandes empresas midiáticas, oferecendo informações geralmente não encontradas nestes últimos, seja devido à proposta dos endereços em estudo, que em linhas gerais se relaciona à criação de redes de solidariedade e à efetivação de demandas sociais, políticas e culturais.

\footnotetext{
${ }^{6} \mathrm{http}: / / \mathrm{www}$. midiaindependente.org/ ${ }^{7}$ http://www.intervozes.org.br/

${ }^{8}$ Dados do Comitê Gestor da Internet no Brasil apontam para uma base de $38 \%$ da população com acesso a Internet (COMITÊ GESTOR DA INTERNET NO BRASIL, 2012) http://cetic.br/usuarios/tic/2011-totalbrasil/rel-geral-04.htm
} 


\title{
míDiA

De algum modo, fora da ideia de vendas e da espetacularização, tais iniciativas afastam-se da lógica mercadológica dominante - sejam as redes de televisão, as produtoras comerciais ou aos conglomerados de cinema - e se apresentam como alternativas ao modo tradicional de produção. Com isso, acabam por atender, em tese, à persistência de visões de mundo diferentes daqueles difundidos na "grande mídia". Ações que permitem oferecer uma alternativa à sociedade, bem como manter a circulação de do produto audiovisual local. Neste sentido, cada entidade analisada, cada uma a seu modo, dialoga com a discussão da democratização da informação através da Internet.

A forma como os dispositivos midiáticos digitais se organizam (aspecto fundamental num endereço eletrônico, na medida em que pode abrir espaços de emissão para o receptor) pode lançar luz sobre quanto espaço de comunicação é efetivamente dado aos "de fora", e como se configura a abertura para a participação e para a comunicação dos visitantes. São relevantes elementos como intervenções abertas a toda comunidade ou restrita a membros, potencialidades de ações colaborativas e o alcance das ações e discussões empreendidas, passíveis de detecção através da comunidade virtual.

O processo de pesquisa aqui desenvolvido guarda semelhanças com o conceito de Netnografia, ou Etnografia Digital, desenvolvido por Robert Kozinets. Segundo o autor, a Etnografia Digital consiste numa

\begin{abstract}
Descrição escrita resultante do trabalho de campo que estuda as culturas e comunidades on-line emergentes, mediadas por computador, ou comunicações baseadas na Internet, onde tanto o trabalho de campo como a descrição textual são metodologicamente conduzidas pelas tradições e técnicas da Antropologia cultural (KOZINETS apud CERQUEIRA, 2010, p. 36).
\end{abstract}

Kozinets (idem) indica as seguintes etapas de pesquisa: entrée cultural (definição de objetivos, grupos, tópicos e espaços a serem estudados), coleta e análise de dados, ética de pesquisa (identificação do pesquisador perante os sujeitos investigados) e feedback (apresentação de relatório final aos membros dos grupos). Pretendemos seguir as etapas de pesquisa sugeridas pelo autor, com o acréscimo - como já indicado anteriormente - de entrevistas presenciais com administradores, colaboradores e usuários de alguns sites selecionados. 


\section{míDiA

No que se refere ao contexto paraibano, faz-se necessário compreender que o movimento de audiovisual paraibano não é instituído, formalizado ou possui uma composição hierárquica definida. Podemos considerá-lo como um conjunto de entidades e ações que visam os interesses do audiovisual paraibano e suas relações com a sociedade.

Sua composição é plural e multifacetada, tendo como seus participantes entidades classistas (ABD-PB), independentes (Cineclubes, movimento pelo cine São José, Moinho de Cinema da Paraíba, Fundação Acauã, etc.), órgãos e instituições governamentais (UFPB, UFCG, UEPB, SeCult/PB, Funjope dentre outros). Organizações que operam na discussão com a sociedade e com as esferas pública e privada. Buscam construir espaços de interesse profissional ou voltados à função social, em que o audiovisual contribui para o bem estar e para a cidadania. De formas e com papeis distintos, investem nos campos do fomento à produção, formação qualificada, distribuição, exibição e circulação de materiais audiovisuais e promoção de festivais para o acesso da população. É visível que neste contexto, ocorrem processos de disputa de hegemonia interna ou infrapolítica, como definiria Scott (apud MORAES, 2008).

A ABD-PB (Associação Brasileira de Documentaristas - secção Paraíba) é uma entidade de classe sediada em João Pessoa, capital do estado da Paraíba e tem como seu principal objetivo é apoiar a realização e produção audiovisual em vários suportes, principalmente ao curta-metragem. Atualmente, a ABD-PB tem sede própria e onde realiza palestras, cursos, mostras e oficinas e abriga um dos pontos de cultura do Programa Cultura Viva (MinC), a URBE Audiovisual (ABD-PB, 2012). Sua atuação midiática se utiliza de um website e do microblog twitter para divulgar informações relativas ao audiovisual paraibano, nacional e internacional, sobre editais, programação de exibição, convocatórias, divulgação da produção independente local, além de emitir opiniões acerca das políticas públicas do audiovisual nas esferas local e nacional.

O Moinho de Cinema da Paraíba é uma organização não governamental, sediada em Campina Grande, no agreste paraibano composta por 13 membros, que tem por objetivo o fomento, apoio, disseminação e distribuição da produção videográfica/cinematográfica da Paraíba. O Moinho utiliza o twitter para transmitir informações, compartilhar conteúdo 


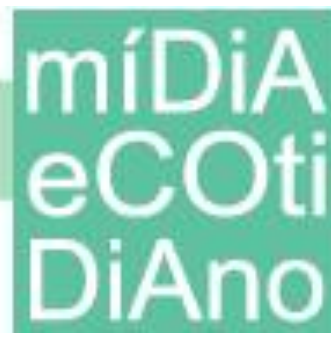

PPGMC

relativo à comunidade de audiovisual, bem como fazer chamadas e comunicados de atos e eventos de mobilização relativos a demandas de necessidade dos movimentos em geral.

Dentre os principais cineclubes podemos elencar o Tintin Cineclube, em João Pessoa, Mário Peixoto, em Campina Grande e Walter Carvalho, em Sousa. Na Paraíba atualmente existem sete festivais de cinema, que foram criados ou estimulados a partir de articulações do movimento em parceria com universidades ou fundações, que acabou por criar um calendário anual interno de festivais. Os festivais que são realizados anualmente são: Fest Aruanda (João Pessoa), Comunicurtas (Campina Grande), Cinema com Farinha (Patos), CineCongo (Congo), Curta Coremas (Coremas), CurtaCuité (Cuité), Festival de Mini Mídias (Alagoa Grande).

Os cineclubes e festivais também se utilizam do twitter para fazer divulgação das suas programações e criar uma aproximação com o seu público. No entanto, também fazem uso da rede social facebook para divulgar suas atividades, bem fazer convocatórias de seletivas para compor sua grade de programação através das chamadas fanpages e grupos de discussão. Também é nessa rede social onde se estabelecem os principais contatos internos entre estas organizações e outros entusiastas do audiovisual.

As entidades do movimento do audiovisual paraibano utilizam tecnologias de informação e comunicação desde agosto de 2003, na ocasião foi instaurada a lista de discussão da ABD-PB. Esta tem por objetivo promover troca de informações, debates e deliberação de estratégias de ação da classe reivindicando demandas e políticas de estímulo à produção, circulação e formação no campo do cinema e vídeo. A lista agrega seus sócios, entidades parceiras de caráter independente e pública criando uma rede de diálogo que deram vazão, de maneira direta e indireta, ao crescimento tanto das produções, quanto a formações de plantel na área técnica e o aumento de espaços para exibições.

É perceptível que o uso da lista aproximou os realizadores do estado como um todo, que antes se viam isolados ou pouco comunicativos internamente, e a partir de trocas, fomentaram a criação de festivais que contemplam todas as mesorregiões da Paraíba, bem como ajudou de maneira indireta a expandir a produção no âmbito estadual, através dos seus cursos em que as chamadas eram de divulgações virtuais. 


\section{míDiA

Com os anos, emergiu o uso de outros dispositivos como twitter, além de somaremse à iniciativa da ABD-PB outros coletivos e cineclubes. $\mathrm{O}$ que fortaleceu e distribuiu bem as frentes de ação do movimento. Buscando uma dinamização e uma interação menos formal com a sociedade, as entidades recorreram à criação de fanpages na rede social Facebook, bem como a criação de grupos de discussão ${ }^{9}$ que possam ser consideradas comunidades virtuais de diálogo e interação entre seus participantes.

\section{Conclusão}

Diante do exposto neste projeto, ressaltamos a importância que o desenvolvimento desta pesquisa terá para o movimento do audiovisual paraibano, avaliando suas estratégias e auxiliando no processo autocrítico das entidades. Por causa da filiação a uma das entidades e estarmos envolvidos no movimento, compreendemos o exercício crítico da pesquisa como fator positivo para melhorar o norteamento das discussões.

Atualmente a pesquisa se encontra em fase de levantamento bibliográfico, que definirá os conceitos de contra-hegemonia, apropriação e uso, mídia independente, permitindo um direcionamento coerente do objeto em questão, auxiliando na criação do roteiro metodológico a ser seguido no intuito de obter um resultado satisfatório. É válido ressaltar que por ser um objeto em constante transformação é possível que o processo metodológico sofra algum tipo de alteração que venha a colaborar melhor com a pesquisa, sem prejudicar seu andamento nem o caráter isonômico que se pretender ter durante o processo.

Reconhecemos o potencial democrático embutido na tecnologia e nos dispositivos midiáticos da Internet, no que tange a propagação da cidadania cultural através de uma mídia independente, alternativa e contra-hegemônica. Acreditamos que este potencial pode ser explorado de modo a transformar criticamente a realidade. Dito isto, é necessária a ressalva de que tentaremos evitar qualquer pré-noção "apocalíptica" ou "integrada" em relação ao desenvolvimento da mídia e principalmente em relação aos sites especificamente

\footnotetext{
${ }^{9}$ Como, por exemplo, o grupo A Paraíba precisa Ser Assistida/ Movimento pelo Cinema Paraibano, com 510 membros, e foi criada para articular o debate entre o movimento e o governo estadual na liberação de mais verbas públicas para o setor.
} 


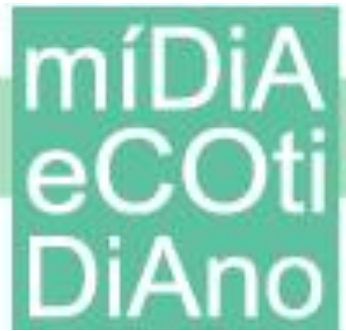

estudados, não porque pretendemos sustentar pretensões de neutralidade ou imparcialidade - afinal, um jornalista é um dos primeiros profissionais a reconhecer o vazio do termo mas porque tal cautela é necessária no estudo de um tema tão relevante, polêmico e heterogêneo. Deixar os dados encontrados e os sujeitos investigados, através da mediação do instrumental teórico, construírem os resultados, é a melhor maneira de desenvolver uma pesquisa deste tipo.

\section{Referências}

BURGOS, Raúl. Da democratização política à radicalização da democracia: novas dimensões estratégicas dos movimentos sociais. In: DAGNINO, E.; TATAGIBA, L. Democracia, sociedade civil e participação. Chapecó: Argos, 2007.

CASTELLS, Manuel. A galáxia da internet: reflexões sobre a internet, os negócios e a sociedade. Rio de Janeiro: Jorge Zahar, 2003.

DOWNING, John D. H. Parceiros não comunicativos: análise da mídia dos movimentos sociais e os educadores radicais. In: Matrizes, Vol. 3, N. 2 . Perspectivas autorais nos estudos de comunicação vi. São Paulo: USP, 2010.

Mídia radical: rebeldia nas comunicações e movimentos sociais. São Paulo: Ed. Senac, 2002.

FESTA, Regina. Movimentos sociais, comunicação popular e alternativa. In: FESTA, R.; LINS DA SILVA, C. Comunicação popular e alternativa no Brasil. São Paulo: Paulinas, 1986.

GARCIA, José Luís. Sobre as origens da crítica da tecnologia na teoria social: Georg Simmel e a autonomia da tecnologia. Scientiae Studia, São Paulo, v. 5, n.3, p.287-336, 2007.

LACERDA, Juciano Sousa; MAZIVIERO, Helena. Pesquisa da pesquisa sobre usos e apropriações das TIC's: um balanço aquém das expectativas. In: XXXIV Congresso Brasileiro de Ciências da Comunicação: Quem tem medo da pesquisa empírica. São Paulo: Intercom/Adaltech, 2011. v.1. p. 1-15. Disponível em: 〈http://www.intercom.org.br/papers/nacionais/2011/resumos/R62376-1.pdf> Acessado em 30 de maio de 2012

LEVY, Pierre. Cibercultura. São Paulo: Ed. 34, 1999. 
MAFFESOLI, Michel. O tempo das tribos: o declínio do individualismo nas sociedades de massa.

Rio de Janeiro: Forense Universitária, 1998.

MORAES, Dênis de. Comunicação alternativa em rede e difusão contra-hegemônica. In:

COUTINHO, Eduardo G. Comunicação e contra hegemonia. Rio de Janeiro: editora UFRJ, 2008.

PAIVA, Raquel. Contra-Mídia-Hegemônica. In: COUTINHO, Eduardo G. Comunicação e contra hegemonia. Rio de Janeiro: editora UFRJ, 2008.

PASQUALI, A. Um breve glossário descritivo sobre comunicação e informação. In MARQUES

DE MELO, J.; SATHLER, L. Direitos à comunicação na sociedade da informação. São Bernardo do Campo, SP: Umesp, 2005.

PERUZZO, Cicília M. Krohling. Desafios da comunicação popular, comunitária e alternativa na cibercultur@: Aproximação à Proposta de Comunidade Emergente de Conhecimento. Trabalho apresentado no Grupo de Trabalho "Comunicacion Popular, Comunitaria y Ciudadania", $X$ Congresso Latinoamericano de Investigadores de la Comunicación, realizado na Universidad Javeriana, Bogotá, Colômbia, 22 a 25 de setembro de 2010. Disponível em: <http://www.intercom.org.br/papers/nacionais/2010/resumos/R5-3359-1.pdf> Acessado em 20 de outubro de 2011.

RAMOS, Murilo César. Comunicação, direitos sociais e políticas públicas. In: MARQUES DE MELO, J.; SATHLER, L. Direitos à comunicação na sociedade da informação. São Bernardo do Campo, SP: Umesp, 2005.

WOLTON, Dominique. Internet, e depois? uma teoria crítica das novas mídias. Porto Alegre: Sulina, 2007. 